\title{
P 1. 高圧セルロースアセテート膜等電点電気泳動装置の改良と 血清蛋白分画への応用
}

\author{
○長 裕子・芝紀代子（東京医歯大・検査・生化学） \\ 戸田年総・大橋望彦 (都老人研・生化学) \\ 中尾真 (昭和大・歯・第 3 補綴)
}

（はじめに）

すでに我々はセパラックスE F（以下セア膜）を支持体と する高圧セルロースアセテート膜等電点電気泳動洁置を考案 し、その装置を用いての操作法の至適化を行なった。その結 果、膜を三枚重ねて等電点電気泳動を行なっても、タンパク 泳動パターンにずれのない鮮明な像が得られ、タンパク染色 榶タンパク染色、特異タンパク検出と三通りの違った情報が 得られた。

しかし初期に考案した装置を使用していくうち、いくつか の改良すべき点がみつかった。ひとつにはセア膜をのせるア ルミブロックにガラス板を張り付けていたため、破壊しやす く、トラブルの原因となることである。 また、高圧での泳 動に耐えられるように0 ${ }^{\circ} \mathrm{C}$ 付近まで邻却しているため、試料 塗布時の蓋の開閉が膜面での結露の原因となることである。

そこでまず第一に泳動膜支持台をセラミックブロックに換 えた。広域のセパラインを用いて、セパ膜を5枚重ねて泳 動を行ない、5つの異なった情報が得られる方法へと発展さ せたので報告する。

もうひとつの改良点は、予嗝泳動後の血清塗布時、蓋をあ けることなく釦布できるように工夫した点である。その効 果についても報告する。

(材料及び方法)

試料は東京医科歯科大学附属病院患者及び職員の血清を用 いた。

高圧セルロースアセテート膜等電点電気泳動法は我々の至 適化した方法によった"1。

膜を 5 枚重ねて泳動後、蓋側より1枚目は糖タンパク染色、 2 枚目はタンパク染色、3枚目〜 5枚目は特異夕ンパクの検 出に利用した。ブロッティング法は自然密着法とし、転写 膜はニトロセルロース膜からイモビロンPVDF（ミリポア 社）に変えた。

\section{(結果及び考察)}

膜をのせる支持台を従来のガラス板を張り付けたアルミブ ロックからセラミックブロックに変更した結果、更に冷却効 果が増し、また当然ながら取り扱いも楽になり、より鮮明な パターンが得られるようになった。
本実験では 5枚重ねで泳動を試みたところ、どの膜でも泳 動パターンのずれが全く見られなかった。そこで今回は広 域でのセパラインを用いて、上から 3〜 5枚目の3枚の膜に ついは特異タンパクの検出を試みた。

1枚目は糖タンパク染色、2枚目はタンパク染色、3〜 5 枚目の3枚の膜は、イモビロンPVDF膜に20分自然転写 した。セバ膜に対するブロッティング法に関して種々検討し た結果、自然転写が一番良好な結果がえられることはすでに 報告した ${ }^{2)}$ 。今回、更に感度と鮮明度を向上させるために ニトロセルロース膜よりタンパク結合容量が約3倍高いポリ ビニリデンジフルオリド (PVDF) 膜の使用を試みた。 イモビロンPVDF膜はニトロセルロース膜に比べて、使用 前にメタノール処理といった操作が入るが、タンパクとの結 合か強いため検出感度が高く、かつ、ひとつひとつのバンド がより鮮明であることが分かった。3枚目は I g A、4枚目 はトランスフェリン、5枚目は I g Gの検出を行なった。I g A、I g Gの免疫グロブリンでは特異一次抗体、ペルオキ シダーゼ標識二次抗体での反応で検出すると非特異的なバン ドがでやすいことが分かったのでI g A、I g Gに関しては ペルオキシダーゼ標識一次抗体と反応させた後、ペルオキシ ダーゼ発色させたところ、特異的に検出されることが分かっ た。トランスフェリンに関しては従来通り、一次抗体、二次 抗体を用いて反応を行なった。

I g A、I g G、トランスフェリンともいずれも鲜明なミ クロヘテロジェニティーバンドをとらえることが可能となっ た。 なお我々は、等電点へテロジェニティーのある免疫グ ロブリンをイオン交換クロマトグラフィーで分離精製した際 の等電点分布の検討にも応用して良い結果を得ているので併 せて報告する。

(文献)

1) 芝 紀代子, 他: 生物物理化学, 32 (2):55, 1988

2) 長 裕子, 他: 生物物理化学, 印刷中 


\section{P 2. 2 次元電気泳動法による蛋白質修飾反応の解析}

一表皮トランスグルタミナーゼによるフィラグリンの修飾——

戸田年総・大橋望彦 (都老人研・生化学)

表皮の角層は、基底膜に接着したケラチノサイト （角化細胞）が分化することによって形成される。こ の分化のブロセスにおいて、細胞内では遺伝子発現お よび蛋白質代謝が劇的に变化することが知られている が、最む顥著な変化は顆粒層においてケラトヒアリン 顆粒が出現し、角層で再び消失することである。ケラ トヒアリン顆粒の主要な構成蛋白質であるブロフィラ グリン（分子量 > 200kDa）は、顆粒の消失時期に細胞 内のセリン性プロテアーゼで切断されてフィラグリン （分子量 $49 \mathrm{kDa}$ ）に変るが、このとき同時に等電点の シフト（p７から p| 9）あ見られる。一方、分化に 伴って表皮型のトランスグルタミナーゼが誘導される が、従来この醭素の生理機能はインボルクリンを架橋 し、角質外套を形成することであると考えられてきた。 しかし、フィラグリンの等電点シフトむまたトランス グルタミナーゼの作用による可能性があるため、今回 我々はこれを 2 次元電気泳動によって解析した。

\section{【方法】}

1.ラット表皮細胞の調製：Wistar系 2 3日齢ラッ 卜より全皮有を採取、伊藤らの方法で真皮より别離、 スパーテルによる段階的スクレーブ法て、、基底層、中 間層、および角層を単離した。

2.フィラグリンの精製：中間層の細胞より $1 \%(\mathrm{v} / \mathrm{v})$ の酢酸で抽出。pH-4.9沈殿法でプロフィラグリンを除

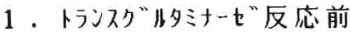
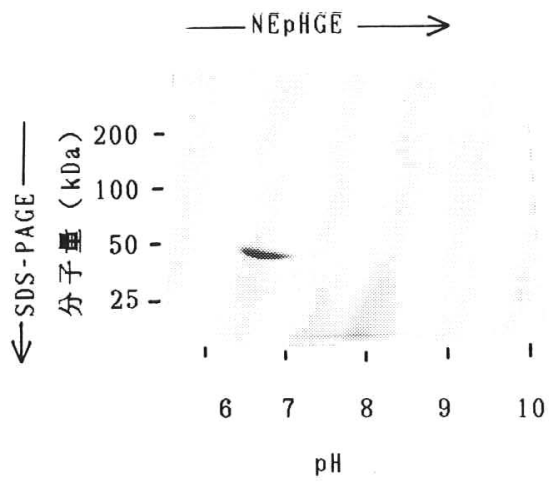

去。Sephacryl S-300 カラムによるゲルロ過、および MON0-S カラムによるイオン交換クロマトグラフィー にて精製した。

3、トランスグルタミナーゼの精製：中間層の細胞お よび角層の細胞より抽出後、硫安分画、等電点電気泳 動、グルロ過、およびアフィニティークロマトグラフ くーにて精製した。

4.トランスグルタミナーゼ活性の測定：精製過程で の活性測定は、カゼインへの $\left[{ }^{14} \mathrm{C}\right]$ プトレシンの取 込によった。等電点シフトの解析は、精製トランスグ ルタミナーゼとのインキュベート前後のフィラグリン を、0'FarreIlのNEpHGE/SDS-PAGE法 2 次元電気泳動で 分析する方法を採用した。

\section{【結果】}

1 . 角層のトランスグルタミナーゼは、フィラグリン を良い基質としたが、中間層の醅素（活性型）はカゼ インを基質とする場合と同程度であった。

2. 角層のトランスグルタミナーゼは、フィラグリン の等電点をシフトさせる作用のあることが確認された。 (下図)

\section{【考察】}

表皮細胞内でのフィラグリンの等電点シフトには、 トランスグルタミナーゼの関与が示唆された。

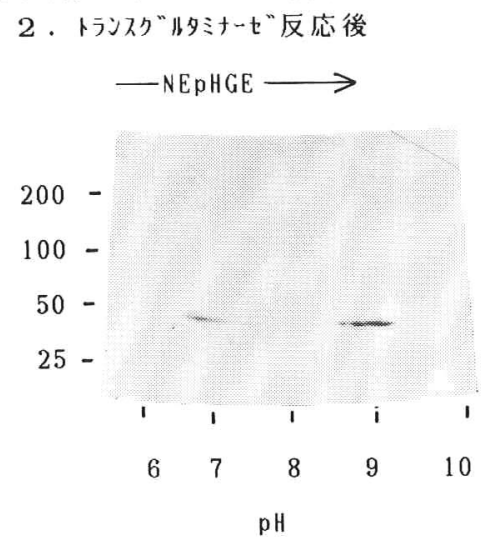




\title{
P 3. 滬液の 2 次元電気泳動法による分析
}

\author{
一午の 1 . 正常ヒ卜涙液の 2 次元電気泳動像
}

\author{
三井清次郎・栗本晋二 (山口大・医・眼科) \\ 中村和行・竹尾和典 (同上・第 1 生化学)
}

[目的］涙夜は涙腺により産生され眼球の前眼部を流 動後添道を経て鼻腔内に排泄される。今回我々は正常七 ト涙夜蛋白をミクロ二次元電気泳動法とイムノブロット 法を用いて分析したので報告する。

[材料、方法]

1. 涙液採取および蛋白量測定：沪花は $20 \mu 1$ の減菌 生理食塩水を点眼し下添点を軽く圧迫後瞬目させ、直ち にHt測定用のガラスキャピラリーにて内眼角付近より採 取し、水上の試験管に移した。この操作を15分毎に行い プールサンプルとし使用するまで-20 ㄷで冷凍保存した。 添夜蛋白震度は牛血清アルブミンを標準蛋白に用い Lowry 法にて測定した。

2. 二次元電気泳動：一次元目は等電点電気泳動法を 行なつた。涙液にショ糖を $40 \mathrm{mg} / 100 \mu 1$ になるように加 え泳動用試料とし、このつち20 クリルアミドキャピラリーゲルを用い、Ampholine は $\mathrm{pH}(3.5-10)$ と $\mathrm{pH}(3.5-5)$ を4:1 の割合に混合した。氷中 で定電流 $0.8 \mathrm{~mA}$ にて泳動を開始し、電圧が $300 V$ に㫒し た後定電压300Vにて20分泳動した。二次元目はSDS ポリ アクリルアミドゲル電気泳動を行なった。一次元目の泳 動終了後キャピラリーゲルを1\%SDS ポリアクリルアミド グラジエントゲル(4-17\%) の上部に重層した後、分子量 マーカーの入ったアガロースゲルを両端にセットし、室 温で定電流80mAにてBPB ラインがゲルの下端より約 $15 \mathrm{~mm}$ の位置にくるまで泳動した。同じ涙液試料を用いて同時 に 4 枚のゲル泳動を行い、内 2 枚は直ちに coomassie brilliant blue R-250(CBB) を用いて蛋白染色を行い、 残り 2 林はイムノブロット用とした。

また血清は涙液と蛋白浱度が同じになるよう調製し同 様に泳動, 染色した。

3.イムノブロット：二次元泳動終了後直ちにセミド ライブロッターにて涙夜蛋白をゲルからニトロセルロー (kD) $200^{-}$

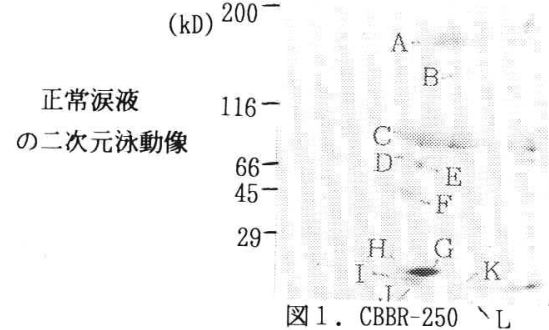

図 1. CBBR-250`L を用いた蛋白染色像

ス膜(NC) (Millipore $0.22 \mu \mathrm{m}$ )に転写した。転写は定電 圧 $6 V$ で室温にて 2 時間行なった。転写後NC膜上の涙液蛋 白は一次抗体（ヤギ抗ヒト血清抗血清、或いはヤギ抗ヒ 卜alpha-1-antitrypsin( $\alpha 1-A T)$ IgG） と二次抗体（家鬼 抗ヤギIgG ペルオキシダーゼ標識化抗体) を用い4-加代 1ーナ外ーを基質とし免疫染色を行なった。

[結果]

1. 添液蛋白量：採取涙夜の蛋白濃度は $1.10 \pm 0.15$ $\mathrm{mg} / \mathrm{ml}$ となり、生理食塩水にて 5 倍に希釈されたと考 られるので涙液蛋白濃度は $5.50 \pm 0.75 \mathrm{mg} / \mathrm{ml}$ となり血清 蛋白量の約 $1 / 15$ であつた。

2. 涙液の二次元電気泳動像：図 1 に示すように CBB を用いて蛋白染色すると、肉眼で判別できるものが12ス ポット認められた。100kD 以上の高分子領域では、160kD のIgA と思われるスポット(A) と約130kD のスポット

（B）のみであった。30 100kDの領域では、アルブミンと 思われるスポット(E) は小さく全蛋白に占める割合は少 ないと思われた。またアルブミン(E) と70 100kDの幅の 広い淡く染色されるスポット(C) に挟まれるように線状 の鮮明なスポット (D) が認められた。30kD以下の低分子 領域では $6 \supset$ のポット(G L) が認められた。図 2 に示 すように抗ヒト血清抗血清を用いて免疫染色すると、100 $\mathrm{kD}$ 以上の高分子領域ではCBB 蛋白染色では認められなか つたスポット(M,N) が2つ染色された。スポット(B) は CBB 蛋白染色に比べ浱く染色された。30 100kDの領域で はCBB 蛋白染色で認められる全てのスポットが染色され た。逆に、30kD以下ではCBB 蛋白染色で認められる $6 \supset$ のスポットは全てが染色されず、CBB 蛋白染色では認め られなかったスポット(0)が1つ染色された。眓3に示 すように抗 $\alpha 1$-AT抗血清を用いて免疫染色すると、スポ ット(D) 付近に2つまた $\operatorname{Ig} A(A)$ に一致する幅広いスポッ トの3つのスポットが認められた。

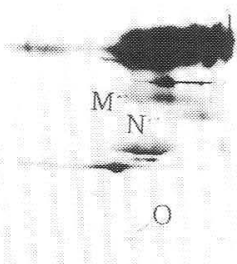

図 2. 抗ヒト血清抗血清 を用いた免疫染色像

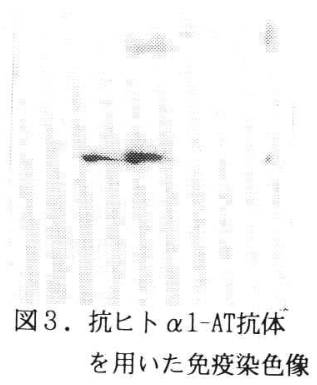




\section{P 4. 2 次元電気泳動法による円口類の血清および藏器蛋白質の解析（Ｉ）}

○今井利夫・中村明宏・永田昭人・吉田光孝 (東邦大・理・生理化学)

[目的]

円口類は現存する脊椎動物の中で最も原始的な生物であ ることから高等動物の原型を知りえると同時に脊椎動物の進 化の過程を検索するうえで動物学上興味が持たれている。

今回、円口類の生化学的研究の一環として 2 次元電気泳動 法を用いヌタウナギ（Eptatretus burgeri）およびメクラウ ナギ (Mixine garmani) の血清および葴器蛋白質の解析を試み たので報告する。

[材料および方法]

ヌタウナギおよびメクラウナギの血清は頭部を固定し尾 部洞に滞留した血液を採取後、血清に分離した。

臓器（脳、心臓、肝㙎、腎脿、骨格筋、小腸、卵单、精单） は Lysis 緩衝液 [ $2 \%$ Nonidet P-40,10mM Tris-Hc1 (pH8.8) ImM phenylmethylsulfonyl fluoride] でモジネート後, 9.5 M 尿素・ 2 \% アンホライン (pH 3.5-9.5) 混液を添加し分析用 試料とした。

2 次元電気泳動法 ${ }^{1,2)}$ は 1 次元目に $2 \%$ アンホライン $(\mathrm{pH}$ $3.5-9.5)$ を含む $4 \%$ PAG $(0.2 \times 10 \mathrm{~cm})$ を用い $120 \mathrm{~V} /$ 况で 7 時間（血清試料では60V/5ルで 8時間）通電した。2次元目 は $1 \%$ SDS を含む $10 \%$ PAGスラブゲルを用い $20 \mathrm{~mA}$ 定電流下 に電気泳動を行なった。

泳動後のゲルは 10 \% TCA にて固定後、CBB R-250にて検出 反応を行ない、得られた各スポットはMW $\times 10^{-3} / \mathrm{pI}$ で表現し た。

[実験結果および考察]

各缄器および血清中にはそれぞれヌタウナギが 60 180 種 類、メクラウナギでは 90 150 種類の蛋白質の存在が確認で きた。これら蛋白質の多くは MW 30,000 95,000,pI 4.5 7.0 に存在し、円口類の各臑器間での傾向も比較的近似して いることが分かった。

特に、種内の各臓器に共通するタンパクスポットとしてヌタ ウナギでは $32 / 7.7,38 / 7.8,42 / 6.3,43 / 7.9$ および55/5.4が認 められ、メクラウナギでは $28 / 7.3,33 / 8.0,38 / 7.8$ および 85/7.2の存在が確認できた。

一方、各葴器に特異的と考えられるタンパクスポットとして ヌタウナギでは脳50/6.4,43/5.4,22/9.5, 心筋80/6.9, 肝臓 48/4.1, 骨格筋 $70 / 7.4$ が、メクラウナギでは心筋 $22 / 7.3$, 肝 葴53/4.6 ,骨格筋 $27 / 4.5$ が確認できた。

今回の検討より、高等脊椎動物のそれとは異なり円口類に
比較的特異的とおもわれるいくつかのタンパクスポットの存 在が確認できた。

メクラウナギの藏器パターンの一部を図 1 および 2 に示し た。

図 1 メクラウナギ肝䑏の 2 次元電気泳動像

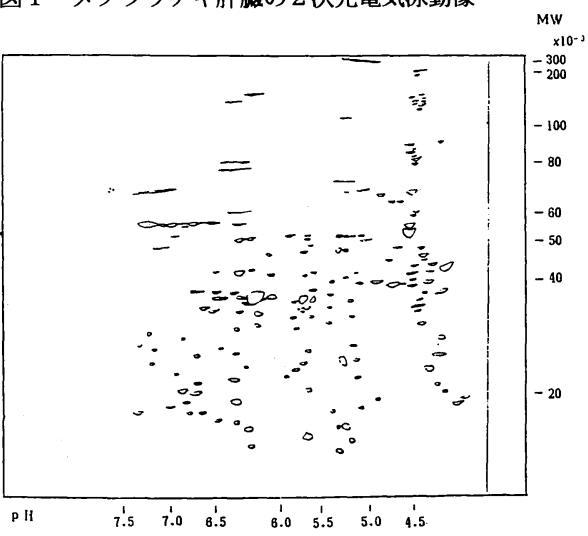

図 2 メクラウナギ骨格筋の 2 次元電気泳動像

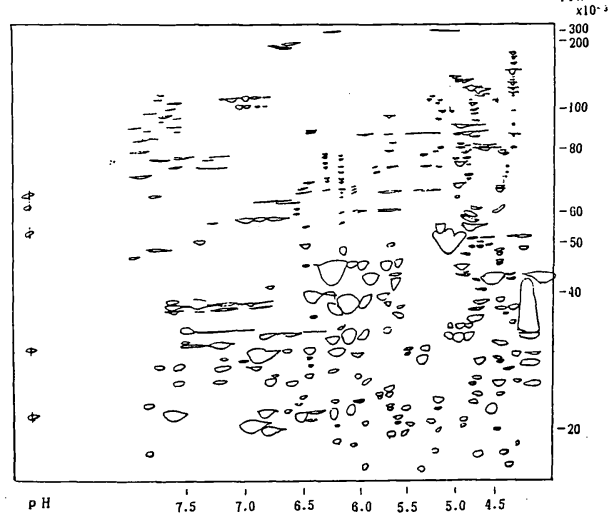

文献

1) 貞広荘太郎、他; 生物物理化学, $27,181,1983$

2) 貞広荘太郎、他; 同上 $, 28,167,1984$ 


\title{
P 5. 高活性の唾液腺型（S-) アミラーゼ・マイナーコンポーネント $\left(\mathrm{S}_{3}\right)$
} を伴う高アミラーゼ血症

\author{
○足立香子・戸沢辰雄（兵庫医大・中検）
}

血清中アミラーゼ活性が上昇するに従い、アイソザイ 么電気泳動像上のコンポーネント活性は增加し、結果と して認めえるマイナーコンポーネント数も増加する。特 にアミラーゼの貯留巣がある場合はそれが顕著である。 通常、増量するアミラーゼが、羘型、唾液腺型にかかわ らずそのコンポーネントの活性順位は、陽極にあるもの ほど低くなる。しかし $\mathrm{S}_{2}$ の活性よりも $\mathrm{S}_{9}$ の活性が優位 ないしは同等の高 $\mathrm{S}_{3}$ 活性を示す症例をこれまでに3例経 験し、それが後天的異常であると推定した。

\section{《症例》}

症例KS 70才 男性 多発性骨髄腫 (IgA-kappa) アミラーゼ活性 $3074 \mathrm{U}$

症例TK 55才 女性 卵巣癌 アミラーゼ活性 $462 \mathrm{U}$ 症例ST 68才 女性 卵巣癌 アミラーゼ活性 $1034 \mathrm{U}$ （アミラーゼ活性の正常值は130〜400U）

\section{《方法》}

アイソザイム分析はタイタンIIILipo膜(ヘレナ)を支持 体とし、陽極側にトリスグリシン緩衝液( $\mathrm{pH} 9.1$ ) 陰極側 にバルビタールナトリウムホウ緩衝液 (pH8.9) を用い、氷 冷下、250volt，40分間電気泳動を行い、ブルースターチ を用いて活性染色を行つた。

$\mathrm{S}$ 型アミラーゼの阻害試験は小麦アミラーゼインヒビ ター(シオノギ) と $\mathrm{S}$ 型モノクロナール抗体(アイソアミ ラーゼ測定用試薬、ベーリンガー)を用いて行った。

\section{《結果》}

アイソザイム分析の泳動上にみられた活性帯数は、症 例KSでは Pーアミラーゼが1本(活性比: $16 \%$ ), Sーアミ ラーゼが 6 本 $(33 \%, 11 \%, 27 \%, 9 \%, 4 \%, 1 \%)$ 症例TKは P ーアミラーゼが2本 $(33 \%, 3 \%), \mathrm{S}$ ーアミラーゼが4本 $(4$ $8 \%, 6 \%, 9 \%, 3 \%)$ 。症例ST仙 P ーアミラーゼが2本 $(40 \%$, $6 \%), \mathrm{S}$ ーアミラーゼが 5 本 $(36 \%, 7 \%, 8 \%, 2 \%, 1 \%)$ であ つた。いずれの症例も $\mathrm{S}_{2}$ の活性よりも $\mathrm{S}_{3}$ の活性の方が 高值を示した。尿中のアミラーゼは症例KSでしか確認し ていないが血清と同様に $\mathrm{S}_{2}$ より $\mathrm{S}_{3}$ が高值を示した。

症例KSおよびTKの唾液中のアミラーゼアイソザイム分 析を行つた。いずれも正常者と差がなかつた。 症例KSの長女、次女、長女の子二人（いずれも男子）
について、家系調查を行つたが全員正常のアイソザイム パターンであつた。

$\mathrm{S}$ 型アミラーゼ阻害試倹では各症例とも、 $\mathrm{S}_{3}$ は $\mathrm{S}_{1} \mathrm{~S}_{2}$ と同様に阻書された。これは小麦インヒビターと $\mathrm{S}$ 型抗 体のいずれも同様の成績だった。

免疫混合法により、アミラーゼ結合性免疫グロブリン の存在は否定された。

\section{《考察》}

$\mathrm{S}_{3}$ 優位の原因として先天的な異常（ 中アミラーゼアイソザイムが正常であることから考えに くい。しかしそれが血中で何らかの修飾を受けたものか、 あるいは異常アミラーゼ産生細胞（組織）が存在するた

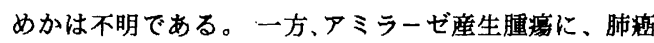

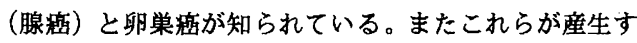
るアミラーゼは $\mathrm{S}$ 型であることが示されている。今回 2 例が卯巣疾であることから、これらの $\mathrm{S}_{3}$ の上昇がアミラ 一ゼ産生腫㿋との関連性が示唆される。しかし、残り 1 例は骨髄腪患者であることは興味深い。さらにアミラー ゼ産生腫榢が産生するアミラーゼは桾鎖による修飾があ ることが知られている。ことから、この可能性が推定さ れる。しかし、これらの昜合アミラーゼアイソザイムパ ターンの特幑があることを明記した報告はない。今回の この特幑あるパターンがそれに相当するか否かは不明で ある。今後症例の蓄積を待ってさらに検討したい。

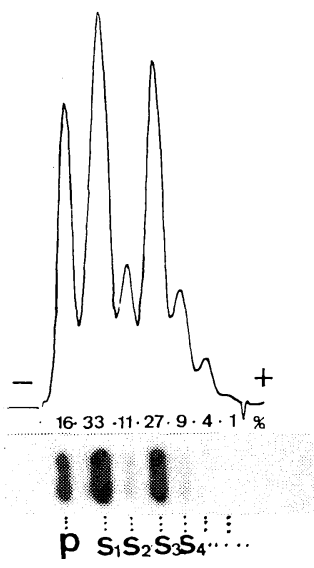


P 6. 界面活性剤添加アガロースゲルとホルマザン呈色反応とを用いた ALP アイソザイム分析の検討

小澤仁子・大久保和弘・樋口義典（チバ・コーニング・ダイアグノスティックス） 菰田二一 (埼玉医大・生化学)

\section{【目的】}

従来よりALPアイソザイムの分析にはポリアク リルアミドゲルやセ・ア膜などが主として用いられ ている。これは寒天やアガロースを単独に支持体と した場合にはアイソザイム相互の充分な分離を得る ことができないためである。このたびチバ・コーニ ングで開発したAＬＰアイソザイムアガロースゲル には界面活性剂が添加されており、A L Pアイソザ イムの良好な分離が得られるようになった。また $\mathrm{A}$ L P 呈色試薬も同時に開発したので、このA L P 専 用ゲルとの組合せによる検討を行い、若干の知見が 得られたので報告する。なお、この呈色試薬の基䝷 はインドキシルリン酸でありホルマザン反応を応用 して発色させる試薬である（Fig.1）。

\section{【方法】}

1. 總 A L P 活性測定: $\mathrm{p}$ 一ニトロフェニルリン酸

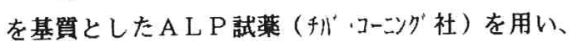

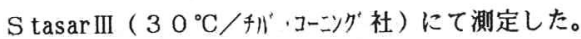
2.ALPアイソザイム分析：ALPアイソザイム アガロースゲルを支持体とし、冷却した A L P バッ ファー( AMP・バルピタール, p H 10.1 / 肺 .コーシグ 社）とアーチ式泳動槽とを用いて、90 V定 電圧で 60 分間の条件で電気泳動を行った。

3. A L P 活性染色: A L P 呈色試藥を蒸留水 $1 \mathrm{ml}$

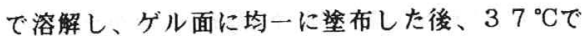
30 分間インキュベーションした。その後 $75 \%$ メ タノール中に 15 分間浸し、つぎに蒸留水で 15 分 間洗浄し、ゲルを乾㷄後、600 n m にてデンシト メトリーを行った。

\section{【結果】}

1. 再現性：ヒト由来A L P コントロール（肝＋ 小晹/Aalto彆) を用いて同時再現性 $(n=4)$ を検討した結果、䀒性A L Pでは $27.1 \pm 1.3 \%$ (Mean \pm S.D.) , C.V.(\%) $=5.0$ 、小晹性 A L P

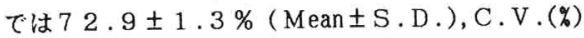
$=1.8$ が得られた。

2. 希釈直線性及び感度：上述のコントロール及び 市販A L P マーカーの希积系列試料（1/16まで)を 調整し㴪定した。この時同時に原液 $3 \sim 1 \mu \mathrm{L}$ 㬁布試
料を測定して比較検討した。結果は、500 IU/Lま での直線性が磼珰され、かつ 1 分画あたりの最低検 出感度は約 20 IU/Lであった。

3. 非特異的反俯： L D H （㑰心筋、Boehringer 社）を約 $10,000 \mathrm{U} / \mathrm{L}$, アスコルビン酸を 100 mg / dl までコントロール血清に添加したが、非特異 的反応は㭲出されなかった。

4. 他法との相関：本法及び他法（Helena社, TitanIIリポ膜およびインジゴ法）にて洞定し得た 48 検体について相関性を検討したところ、各アイ ソザイムの絶対值（總活性俌 $\times$ 分西％）の相関係数 はいずれも0.9以上の良好な結果が得られた。

5.臨床的㛟討例：埼玉医大内科にて臨床診断 の確定した検体 38 例を㛟討したところ、1 7 例に A L P 、を明睹に分離確認することが出来た。その 一部を F ig. 2 に示す。

\section{【考察】}

界面活性剂を添加したAＬＰアガロースゲルを支 持体として用いた本法は、A L Pアイソザイムを良 好に分離することが出来た。さらに特徴としては A L P 1 をより明睹に分别することが可能となった 点である。また、A L P 呈色試薬は従来法 (インジ ゴ法）と比較して感度の高い試薬であった。

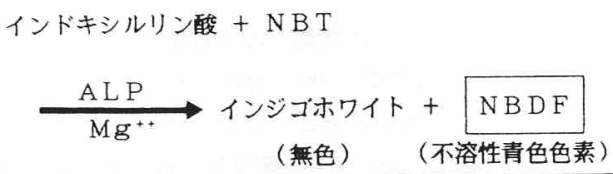

F ig. 1. A L P 呈色試薬の反応原理

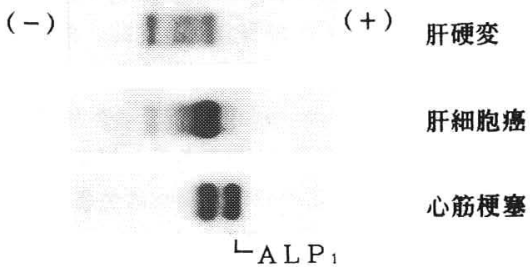

F ig. 2，患者血清の A L P 電気泳動像 
P 7. 一過性 の $\mathrm{LDH}_{3}$ 陰極側過剰活性帯

○桑原純子・戸沢辰雄（兵庫医大・中検）

血清LDHアイソザ仏は通常5分画に泳動されるが、LDH変異、 LDH結合性免疫グロブリンや 腫瑸由来LDHが存在する埸合に 様々なextra bandが出現する。今回、 $\mathrm{LDH}_{3}$ の陰極側に シャープなextra band を有する症例を経験し、そのLDH が $\mathrm{LDH}_{1}$-5 とは異なる性状のものであるとの成績を得た。

\section{[症例]}

29才女性、昨夏 6日間のイント旅行後 15 日目に発熱し、 翌日全身僚念感と高熱のために入院。赤血球中にマラ师ア 原虫封入体を認め、三日熱マラリアと診断され、血管内凝固 症候群を併発した。熱は入院3日目から下がりはじめ、 6日目には平熱となり、封入体も極めて稀にみられる程度 となった。その後肝障害を来している。

\section{[方法]}

LDHアイ州“仏分析は多侈IIILipo膜を支持体とし、通常条 件で電気泳動した後にLD VISP隹゙仏試薬及び乳酸ブランク 試薬（^レ十研究所）を用いて活性染色を行った。分子量 はSphadex G-200㘦ムを用いて測定した。LDH結合性免疫 グロヷリンは免疫混合法で検索した。 extra bandの性状は (1) 56 度 5分、10分、15分、20分、25分、30分の熱試験 (2) 1M、1.5M、2M、3M、4Mの各濃度の尿素：血清を $1: 9$ の割合で混和し、室温で10分反応させた尿素試榆 (3)抗M抗体、強いLDH-MHブエニッ快告作用を持つLDH結合性 IgA例の患者血清、全LDHと結合し anomalyを形成すると 共に失活作用をもつLDH結合性 IgG例の患者血清との反応 で検討した。

\section{[成績]}

患者血清LDHPイ州“仏泳動像上に正常な5つのLDHPイソサ” 仏に加えて $\mathrm{LDH}_{3}$ の陰極側にシャープなextra bandを認めた。 それは入院後3日目までは確認したが、6日目には消失し ていた。極稀にマラ师原虫感染像の見られた赤血球浮遊 液からえた溶血液では $\mathrm{LDH}_{2}$ と $\mathrm{LDH}_{3}$ の陰極側にそれぞ れサブィ“朴”（溶血ベント）を認めたが、対照正常者の溶血 液と比較して、 $\mathrm{LDH}_{2}$ のサブィ”壮に対する $\mathrm{LDH}_{3}$ のそれの 活性比は大きかった。

血清中に認められたextra bandは乳酸ブランク試薬では 染色されなかったことから真のLDHであると判定した。

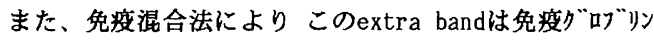
との結合によるものではないと判定した。

耐熟試験では血清extra bandは56度 5分の熱処理で失
活した。溶血波中の $\mathrm{LDH}_{2}$ のサブベンドは56度 30 分の熱 処理で失活を認めなかつたが、 $\mathrm{LDH}_{3}$ のサブベンドは 56 度 5分でわずかに失活を認めたが、10-30分までの熱処理に よる失活の增加は認められなかった。尿素試臨では血 清extra bandは4Mでわずかな失活を認めた。溶血液中

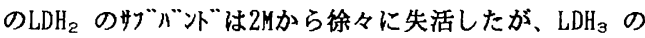
サブn“林の失活は認められなかつた。これらの成績から extra bandは熱耐性では $\mathrm{LDH}_{5}$ と、尿素試験では $\mathrm{LDH}_{1}$ と似

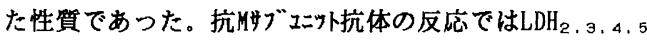
のバンドはanomalyを形成したが、LDH, とextra bandとは anomaly も失活も認めなかつた。また紧ブュニッ快活因子 をもつ患者血清との反応でも $\mathrm{LDH}_{1}$ とextra bandの失活を 認めなかつた。 anomaly を形成し、かつ失活作用をもつ LDH結合性IgG例の患者血清との反応では患者のLDH ${ }_{1-5}$ 全

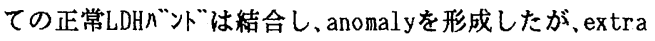
band のみ結合しなかつた。

\section{[考察]}

三日熱マラリリと診断された患者血清中に、一過性に認め られたLDH 3 の陰極㑡に出現したextra band は、真のLDH ではあるがLDH $1-5$ とは異なり、また免疫グロブ归結合物 でもないと判定した。このextra band が正常者の溶血 液中にみられるLDH 3 のサブn“壮である可能性は、同時に 血清中に存在するはずであるLDH 2 のサブベンド、いわゆる 溶血べ决”が存在していないことから考えにくい。また 血管内疑固症侯群治瘜の為に血小板輸血がされているが、 $\mathrm{LDH}_{3}$ の上昇あるいはテーリングも認められなかつたことから 血小板由来LDHも否定される。その他の $\mathrm{LDH}_{3}$ 位に出現

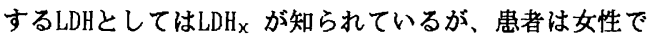
あることからLDHx も否定される。

このLDHは赤血球由来ではあるが、いわゆる溶血バ朴” のLDHとは異なるものと推定される。また、LDH extra band の出現していた時期、マラ师原虫の赤血球感染率の高 い時期が泳ぼ一致していることからマラ师感染との関連性 は否定できず、今後更なる検討が必要である。元来、 マラリア症の日本での発症は見られないが最近の旅行ブーらを 背景に熱帯性のマラリアの感染症は增加しており、マラリア症に 遭遇する機会は今後增大すると予测され、マラリリ症での注 意深い钼察がこの出現の解釈の糸口になるかも知れない。 


\section{P 8. LDH アイソザイムにみられたエキストラバンドの一症例}

○大久保滋夫・豊田幸子・三上恵世・埧重文子・吉野谷定美・大久保昭行（東大病院・検査）

\section{〔目的〕}

日常検査でLDHアイソザイムに依頼があつた険体 の中に、 $\mathrm{L} \mathrm{DH}_{4}$ とL DH5 の間にエキストラバンドが 存在する症例を経験し、若干の倹討を行つたので報告 する。

[淀例]

73 才男性、膿胸の診断で本院内科に入院 生化学検查結果：LDH 219 IU/L（正常值 83 166 $\mathrm{IU} / \mathrm{L}) 、 \mathrm{AST} 43 \mathrm{IU} / \mathrm{L}(8 \sim 33)$ 、AL T $17 \mathrm{IU} / \mathrm{L}$ $(4 \sim 33)$ 、 ALP 292 IU/L $(66 \sim 220) 、 \gamma-\mathrm{GTP}$ $17 \mathrm{IU} / \mathrm{L}(6 \sim 60)$ 、CHE $57 \mathrm{IU} / \mathrm{L}(360 \sim 705)$. AM Y 822 IU/L $(85 \sim 340)$ 、CK 157 IU/L (50 190) 、 $\mathrm{TP} 7.8 \mathrm{~g} / \mathrm{dl}(6.5 \sim 8.0) 、 \mathrm{ALB} 2.5$ $\mathrm{g} / \mathrm{dl}(3.7 \sim 4.9)$ 、 T B $0.2 \mathrm{mg} / \mathrm{dl}(0.2 \sim 1.3)$ 〔試料および测定方法〕

(1) 試料

患者血清および赤血球

（2）LDHアイソザイム测定方法 セルロースアセテート膜（タイタンIII）を支持体に してトリスーバルビタール緩衝液（p H8.6）にて、 $180 \mathrm{~V} 、 25$ 分間泳動後、タイタンLDHアイソザ イム試薬（ヘレナ研究所）にてサンドウィッチ法にて 染色し、固定、水洗、乾燥後、570 n mにてデンシ トメトリーを行つた。

[結果]

（1）患者血清中には $\mathrm{L} \mathrm{DH}_{4}$ と $\mathrm{L} \mathrm{DH}_{5}$ の間に総活性
の約 $10 \%$ のエキストラバンドが認められた。

（2）エキストラバンドの性質

1）LDH染色試薬より基質（乳酸）を除くと染色 されなかつた。

2) $56{ }^{\circ} \mathrm{C} 、 15$ 分間加温で失活した。

3） $2 \mathrm{mM}$ M尿素で失活した。

4） $0.2 \mathrm{mM}$ 荫酸では失活しなかつた。

5）免疫固定法、免疫向流法にて酵素結合性免疫グ ロブリンの検索を行つたが、このどちらの方法 についても免疫グロブリンとの結合は見られな かつた。

（3）赤血球巾にはこのエキストラバンドは見られな かつた。

（4）精液中のLDHアイソザイムを調べが、このエ キストラバンドは無かつた。

（5）血清中のH b 抗原の検索を行つたがH b 抗原は (ー) であつた。

\section{[考察および結論]}

本症例で認められたLDHのエキストラバンドは。 従来報告されていた、 $\mathrm{H}$ b 抗原の複合体、急性肝障害 の極期に見られるバンド、精液中に見られるX型サブ ユニットによるバンドとは異なるものであつた。現在、 ゲル㴔過にて分子量を测定して、免疫グロブリンとの 結合について険討中である。 


\title{
P 9. ALP-Immunoglobulin G 複合体に補体 C (C 3 c) が 結合していた例についての検討
}

\author{
佐藤豊二・鈴木正武・赤井貞彦（新潟県立がんセンター・新潟病院）
}

酸素一免疫グロブリン（E-lg）複合体の歴史をふりか えると, 1964 年のWilding のアミラーゼー $\lg$ の報告から 早くも四半世紀が過ぎた。その間, ALP-lgはNagamine \& Ohkumaにより 1975 年に報告された。その後の多くの 報告では, ALP-lg の分子量は 28 万から90万までいろい ろある $(1-3)$, 我々はCroftonのlimmune complex と 考える概念 (4) 加ら, ALP-lgの分子量の不均一性の原 因の一つには, ALP-lgに補体の結合の有無むあろうと考 えて検討した結果を報告する。

材料之方法

1) 血清は当院入院中の患者より得た。症例 1 は 70 才の 男性でスイ癌; 症例 2 は 72 才の男性で肺癌。

2) Cellulose acetate membrane electrophoresis (CAE), counterimmunoelectrophoresis (CIE) は 以前の報告（5）と同じである。支持体上のALPの活 性染色には 5-bromo-3-indolylphosphate を使 用した。抗ヒト血清はDAKO社のものを使用した。

$3)$ Gel filtration: Sephacryl S-300 $(2 \times 84 \mathrm{~cm})$ を用い, $0.05 \mathrm{~mol} / 1 \mathrm{Tris} / \mathrm{HCl}(\mathrm{pH} 7.4)-0.15 \mathrm{~mol} / 1$ $\mathrm{NaCl}-0.1 \% \mathrm{NaN} 3$ で溶出した（各 $2.5 \mathrm{ml}$ )。

4) アミ/酸阻害試験：L-Phe $(5 \mathrm{mmol} / \mathrm{l}), \mathrm{L}-$ Homoarg ( $5 \mathrm{mmol} / \mathrm{l})$, L-Leu $(0.4 \mathrm{mmol} / \mathrm{l})$ を用 いて行った。熱処理：56 Cまたは 65 Cで 5 分間行っ た。Placental ALPの測定：以前に報告した enzymeimmunoassay (EIA) (6) で行った。 結 果

1) Fig.1はCIEの結果である。症例 1 では, 抗 $\lg G$ また は抗C $3 \mathrm{c}$ と反応して生じた沈降線上に ALP 活性が 認められた。このことはALPが $\operatorname{lgG}$ 及びC $3 \mathrm{c}$ と結合 していることを示した。この複合体の分子量が gel filtration では約 90 万と推定されたてとから, ALP $900 \mathrm{kD}$ と呼ふてとにした。てれに関与した $\lg \mathrm{G} の \mathrm{~L}$ 鎖は不明であった。同様にして症例 2 ではALPが $\lg G \lambda$ と結合しており，分子量が約 45 万であったてとから $\mathrm{ALP}-450 \mathrm{kD}$ と呼ぶことにした。

2) $\mathrm{ALP}-900 \mathrm{kD}, \mathrm{ALP}-450 \mathrm{kD}$ をアミノ酸阻害, 熱 処理さらにPIAPのEIAによる検索加ら, 複合体に関 与したALP臟器非特異型と考えられた。

考察

Circulating immune complex (CIC) にはよく補体
が結合している。ALP- $\lg$ にC 3 c の結合している例を示 したが, 普遍的なものか今後検討したい。ALP-450 kD では臟器非特異型ALP の耐熱性が多少增加している印象 があった， $\lg$ と結合するととによって耐熱性の変化が起と るのかもしれない。

文献：

1) Hattori,Y.et al : Clin. Chim. Acta, $97: 243,1989$.

2) Crofton,PM.et al : Clin.Chim. Acta, 83:235,1978.

3 ) Umeki,K.et al : Jap.J.Clin.Path. (Rinshobyori) $31: 1093,1983$.

4) Crofton,PM.et al. : Clin.Chim.Acta, $111: 257$, 1981.

5 ）佐藤豊二他：生物物理化学, $31: 419,1987$.

6) Sato,T.et al. : Clin.Chim.Acta, $183: 239,1989$.

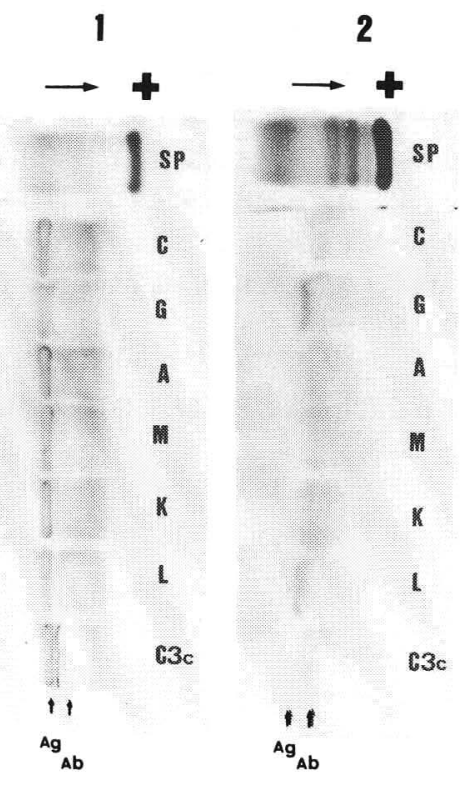

Fig. 1. ALP isozyme patterns by CIE $\mathrm{SP}$, serum protein;C,control;G, A, M, K, L, C $3 \mathrm{c}$ are anti-human antibodies to $\lg \mathrm{G}, \lg \mathrm{A}, \lg \mathrm{M}$, kappa light chain, lambda light chain or $\mathrm{C} 3 \mathrm{c}$, respectively; Ag, antigen; Ab,antibody. 


\title{
P 10. Elastase-1 結合性免疫グロブリンとその検出法
}

\author{
○戸沢辰雄（兵庫医大・中検）
}

七膵Elastase(E)にはE-1とE-2の2種があり、両者の間に は生化学的にも免疫学的にも差がある。血中の醭活性 测定は種々の難があるために、RIA法によるE-1の免疫活 性測定が臨床検査として普及している。血清中のE-1は 遊離E-1ではなく、 $\alpha_{1}$ Antitrypsin( $\alpha_{1}$ AT)ないしは $\alpha_{2}$-macroglobulinとの結合物として存在している。 RIA法では、 $\alpha_{1}$ AT結合E-1と遊離E-1が検出される。昨年 、塚田らは血清Lipase活性の上昇をともなわない、持続 性の高E-1血症の4例の血中に高分子様のE-1を検出して いる。演者は兔疫活性測定による醭素結合性兔疫グ口7゙ リの検出(同定)法を開発し、同様の症例の血中にE-1結 合性IgGを検出した。つまり、新たな醉素結合性免疫グロ ブリの存在が判明した。また、本症例は同時にAmylase (Amy)結合性IgAを併せむつ、示唆に富む症例である。 症例 32才の男性、1986年に慢性膵炎を疑わせる症状が あり、Amy活性の軽度上昇と高E-1活性を指摘されたが、 逆行性脺胆管造影検查、CT検查、超音波検査により膵缄 の異常は否定され、暴状胃と診断された。その後、時々胃 部痛があるだけで、健常生活をしていた。昨年4月、本院 に来院、勿Amy血症と高E-1血症を確認したが、健常者と みなした。その時の検査值は、S-Amy:412 U/L(130-400) 、E-1:1168ng/dl (70-400)、Trypsin:90 ng/mI (100-500) 、Lipase:19 IU/L(7-50)であった。

方法 1)Amy結合性免疫グロブリの検出は免疫混合法で おこなった。2)Amyアイ代”仏泳動は多侈板上でおこなっ た。3)マ久ロAmyおよびマ听-1の検出はSephadex G200 superfineゲ㸝ムタロマグラフィー法でおこなった。4)E-1結合 性兔疫グロブリンの同定は図に示す方法でおこなった。試

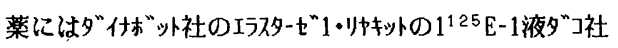
の抗人免疫グロブリ抗体液を用いた。

成績 1)Amyア仪”仏永動像、P1位から陽㓙側へ分離でき ない一連の活性を認めた。2)Amy結合性免疫グロブリは

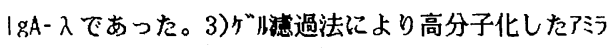
一七゙は認められず、解離したと考えられる。4)ケ”淮過法 により正常人のそれよりも高分子化したE-1のみを認め た。5)E-1結合性免疫グ听”归免疫沈降物中の放射活 性から|gG- $\kappa, \lambda$ と決定した。

考察 RIA法で測定される血中E-1は $\alpha_{1}$ ATと結合してい ることから、 $\alpha_{1}$ ATK対する抗体が存在する可能性もあ る。しかし、この場合には、同じく血中で $\alpha_{1}$ ATと結合し て存在する血清trypsinも持続的に暴常高值になるはず であることからこの可能性は否定される。吅Amy血症の 血清E-1レ゙川は正常であることがしられているが、本症 例の発見はこの検討を改めてする必要性を示唆してい る。何故ならば、LDH、ALP、CK、Amy結合性免疫グロブリリのう ち、前3者間で重複する頻度は大きいが、それらとAmy結 合性免疫グロブリかが重複する頻度は小さい。これは、4者 のうちAmyだけが外分泌醇素であるからと推定されるか らである。E-1結合性免疫グロづリと疾患との関連性は、 塚田らの4例(下痢症、胃湜瘍の疑い、糦尿病、腰椎固定術 を受けた患者の各1例)を併せて考えてむ、Amy結合性免 疫グロブリと同様になさそうである。しかし、E-1結合性 免疫グロブリンを識別する意義は他の酥素結合性免疫グロ ブリのそれよりむ大きい。何故ならば、E-1は膵炎の指標 のみならず、広義の腫瘍マ-かーとしても評価されているか らである。

最後に、E-1測定に御協力下さいました本学核医学・福地 稳教授、同診療部・河中正裕講師に深樈いたします。 文献 1)大山俊郎、他.医学のあ沖み 105:91-97,1978. 2)木村寿成、他. 日本臨床 43秋期臨時増刊号: $472-474$, 1985. 3)塚田敏彦、他.臨床化学 18 補冊:115a,1989.

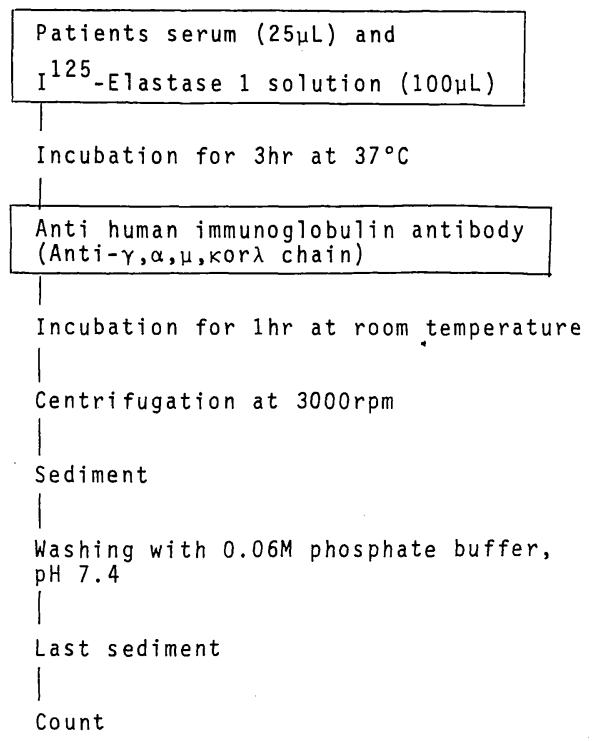

